DOI: https://doi.org/10.34069/AI/2021.47.11.10

How to Cite:

Saltykov, M.A., \& Krasova, E.V. (2021). Trends in development of Russian Far East's fishing industry in context of strategic regional growth. Amazonia Investiga, 10(47), 93-106. https://doi.org/10.34069/AI/2021.47.11.10

\title{
Trends in development of Russian Far East's fishing industry in context of strategic regional growth
}

\section{Тенденции развития рыбной отрасли Дальнего Востока России в контексте стратегического роста региона}

Received: October 10, 2021

Accepted: November 23, 2021
Written by:

Maksim A. Saltykov ${ }^{44,45}$

https://orcid.org/0000-0003-0313-5587

Elena V. Krasova ${ }^{46}$

https://orcid.org/0000-0001-7847-0385

\section{Abstract}

This article is devoted to topical issues of the fishing industry development in the Russian Far East. Far East is the largest and the most abundant with fish resources region of Russia, and also it is the largest territorial administrative unit. The main scientific and practical task the research can help to solve is implementation of strategic prospects and scientific support of the industry development government programs. The aim of the research is to update the trends and identify the main problems of the fishing industry development in the Far East of Russia over the past decade. Methodologically the research is based on the concept of regional economy sustainable development. The article analyzes such indicators of the industry development as: number of enterprises in the industry, number of employees at the industry enterprises, volume of fish products production and processing, level of domestic prices for fish products, fish products consumption volume, fish products export value, volume of investments in fixed assets of industry enterprises. The key trends are identified and the most important problems of the regional fishing industry development are noted. Among such problems: the industry's dependence on the world market situation, insufficient development of domestic market, excessive growth in prices for fish products in the domestic market, low degree of fish products processing, dependence

\begin{abstract}
Аннотация
Статья посвящена актуальным вопросам развития рыбной отрасли Дальнего Востока крупнейшего региона России и наиболее обеспеченного рыбными ресурсами. Основной научно-практической задачей, на решение которой направлено исследование, является реализация стратегических перспектив и научная поддержка государственных программ и стратегий по развитию отрасли. Целью исследования является актуализация тенденций и выявление основных проблем развития рыбной отрасли ДВР за прошедшее десятилетие. Методологической основой статьи является концепция устойчивого развития экономики региона. В статье анализируются такие показатели развития отрасли, как: численность предприятий в отрасли, численность занятых на предприятиях отрасли, объем добычи и переработки рыбной продукции, уровень внутренних цен на рыбную продукцию, объем потребления рыбной продукции, объем экспорта рыбной продукции, объем инвестиций в основные фонды отраслевых предприятий. Определены ключевые тенденции и отмечены наиболее важные проблемы развития рыбной отрасли ДВР. Среди таких проблем: зависимость состояния от мировой рыночной конъюнктуры, недостаточное развитие внутреннего рынка, избыточный рост цен на рыбную продукцию
\end{abstract}

\footnotetext{
${ }^{44}$ Candidate of Economic Sciences, Associate Professor of Department Process machines and equipment, Far Eastern State Technical Fisheries University, Vladivostok, Russia.

${ }^{45}$ Candidate of Economic Sciences, Associate professor at the Department of Economic Theory and World Economy, Vladivostok branch of Russian Customs academy, Vldivostok, Russia.

${ }^{46}$ Candidate of Economic Sciences, Associate Professor of Department of Economics and Management, Vladivostok State University of Economics and Service, Vladivostok, Russia.
} 
of fish products export on Asian countries' consumers.

Keywords: fishing industry, Far East of Russia, fisheries, aquaculture, Far East economy.

\section{Introduction}

The Far East of Russia (Far East, or FER for short) possesses large reserves of marine biological resources that provide both the domestic market for fish products in the country and exports to the world market. The FER's fishery industry is of great socio-economic importance for the country as a whole. Population is provided with fish products, the industry enterprises contribute to the economy of cities and regions, jobs are preserved, export of fishery and aquaculture products is an important source of export earnings.

Long-term prospects for the FER's fishing industry development are outlined in a large number of state programs and strategies of Russian Federation, including: Strategy for the fishery complex development until 2030, Strategy for the food and processing industry development until 2030, Program «Development of the fishery complex», Program «Socioeconomic development of the Far East and the Baikal regions until 2025» and others. The mentioned documents define as a goal the expansion of production and sale of seafood with a high share of added value, the introduction and modernization of up to $40 \%$ of the total industry processing capacity in the Far East territory.

Analysis of the fishing industry current development in Far East, identification of its competitive advantages and disadvantages are important stage in the strategic programs' implementation. The main scientific and practical tasks the research could help solve are the strategic prospects' implementation and scientific support of the decisions made by the industry management. The aim of the research is to update the trends and identify the main problems of fishing industry development in the Far East over the past decade. Fishing industry is considered here as an industrial complex, organically including fishing and aquaculture.

\section{Theoretical Framework}

The research uses fundamental backgrounds of the Food and Agriculture Organization of the на внутреннем рынке, низкая степень переработки рыбной продукции, зависимость экспорта рыбной продукции от азиатских стран.

Ключевые слова: рыбная отрасль, Дальний Восток России, рыболовство, рыбоводство, экономика ДВР.

United Nations, which determines the global development processes of the fisheries sector (FAO, 2021). The theoretical basis of the research is made up of scientific works covering the development trends of the global fishing industry (Pauly, 2008; Rousseau et al, 2019), national and regional aspects of fishing industry enterprises development (Glubokovsky et al, 2018; Zhao \& Shen, 2016), fishing industry activities optimization in the FER's multi-species fishing trades (Lisienko \& Ivanko, 2020). The works (Glubokovsky et al, 2018; Osipov \& Krasova, 2017; Saltykov \& Tkachenko, 2021) present various analysis components of the development specifics of Russian industrial fisheries, aquaculture, fishing fleet, state of fish resources, fich processing and fish consumption. In studies (Zhuk, 2010; Vorozhbit et al, 2018), a methodology for assessing the fishing industry competitiveness in the Far East is considered, indicators for assessing the competitiveness of enterprises in the fishing industry are proposed. The peculiarities of fish cluster formation, its main elements, and the fishing industry structure in the Far East are presented in studies (Fisenko \& Saltykov, 2020; Malenkov \& Dreving, 2009; Saltykov et al, 2020; Terentyeva et al, 2019). We have considered some issues devoted to Russian fishing industry functioning and its competitiveness in our previous works (Kim \& Saltykov, 2020; Saltykov \& Obraztsova, 2020; Zhilina, \& Krasova, 2014).

\section{Methodology}

The research is joined to a methodology of the Food and Agriculture Organization of the United Nations that is used for studying the peculiarities of the fishing industry development in different regions of the world (FAO, 2021). The research uses the trend analysis method with absolute and relative economic indicators, structure analysis with relative indicators, and comparative analysis of time periods. The information base of the research is statistical data of Federal State Statistics Service of Russian Federation for 2010-2019, data of Federal Agency for Fisheries of Russian Federation (F\&A, 2021; FFA, 2021). 


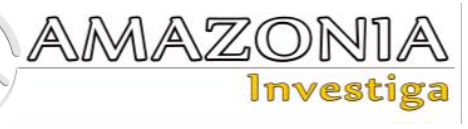

The research of the fishing industry development trends is based on analysis of a number of general and specific indicators which represent comprehensive view of the industry trends and its resource base, on assessment of regional component significance, on assessment of potential for international cooperation development. Comprehensive statistical analysis of the industry includes the following groups of indicators studied in dynamics and structures:

- number of enterprises in the industry;

- number of people employed at the industry's enterprises;

- volume of fish extraction and processing;

- level of prices for fish products;

- volume of fish products consumption;

- value of fish products export;

- volume of investments in the industry fixed assets;

- $\quad$ some other indicators.

\section{Results and Discussion}

Fishing industry is one of the key segments of Russian Far East's economy: about $60 \%$ of the total Russian catch is taken in the Far Eastern basin. The Far East is the largest and most resource-rich macroregion of Russia. The area of the sea and oceanic waters of the Far East is about 3.5 million square kilometers. It includes the waters of the Pacific and Arctic Oceans, as well as six seas: East Siberian, Chukotka, Okhotsk, Beringov, Japan and the Laptev Sea. The FER's scale can be fully attributed to fish resources. Russian Far East covers the fishing zone of the northwestern part of the Pacific Ocean, which annually produces about 3.5 million tons of fish and other aquatic biological resources, which is $72 \%$ of the total Russian catch and about $4 \%$ of the global catch. We should note that Russia is traditionally in 5-6 places in the world in terms of the ocean catch volume, occupying a share of about $4.5 \%$ (FFA, 2021).

Far East as a macroregion is extremely heterogeneous in its geographic and climatic conditions. It includes areas with different fishing potential. For a visual and qualitative assessment fishing industry development, it is necessary to highlight the traditional areas of fish catch and production such as Kamchatka, Sakhalin, Khabarovsk, Primorye and Magadan regions. Figure 1 shows the geographic location of these areas.

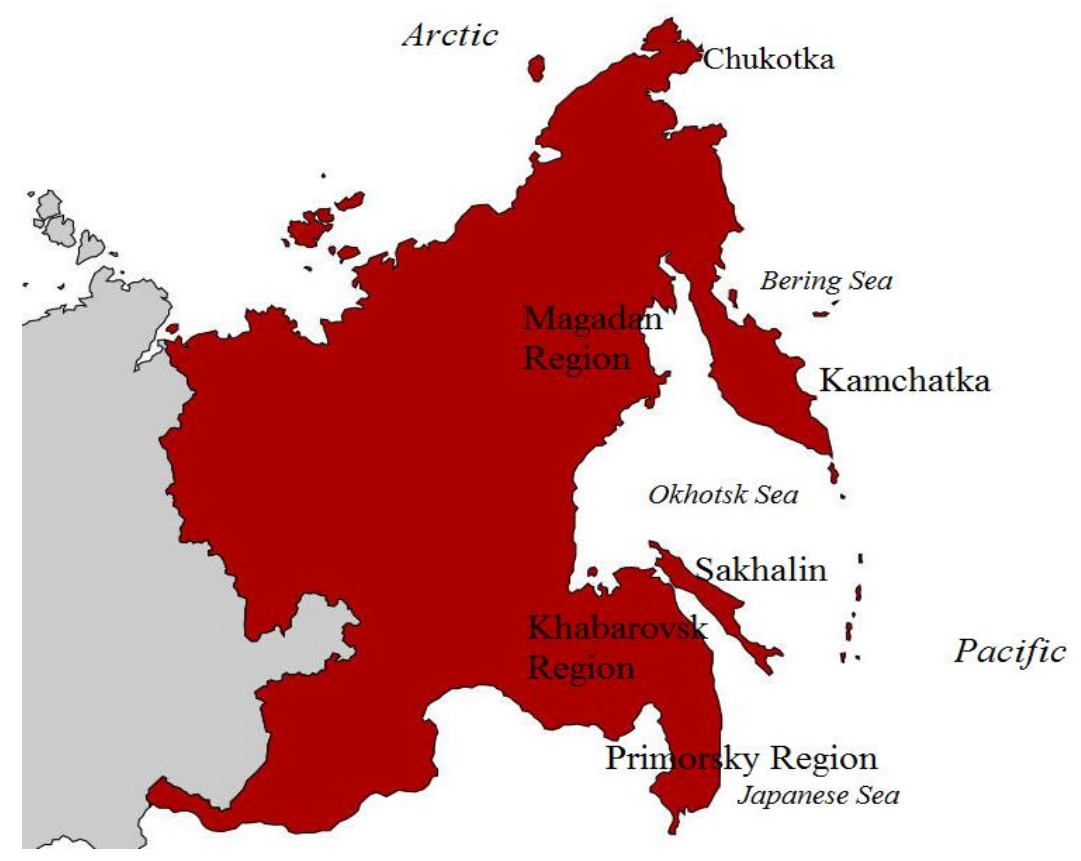

Figure 1. Main catch areas of oceanic fish in the Far East of Russia.

The FER's fishing industry includes 2,650 fishing enterprises, which is $1.33 \%$ of the total number of enterprises in the region, and 225 aquaculture (fish farming) organizations $(0.11 \%)$. Both in fishing and in aquaculture, small businesses and individual entrepreneurs are actively working: their number is 1386 units and 449 units, respectively. The distribution of enterprises in the FER's fishing industry by the main fishing areas is presented in Table 1. 
Table 1.

Total number of fisheries and aquaculture enterprises in Far East of Russia by main catch areas, 2019

\begin{tabular}{lllll}
\hline Areas & $\begin{array}{l}\text { Fishery } \\
\text { enterprises }\end{array}$ & $\begin{array}{l}\text { Aquaculture } \\
\text { enterprises }\end{array}$ & Total & $\begin{array}{l}\text { Share of industry } \\
\text { enterprises in the } \\
\text { total number of } \\
\text { regional enterprises }\end{array}$ \\
\hline Far East (total) & 2650 & 225 & 2875 & $1,4 \%$ \\
Kamchatka & 703 & 11 & 714 & $7,0 \%$ \\
Sakhalin & 683 & 39 & 722 & $4,8 \%$ \\
Khabarovsk & 481 & 25 & 506 & $1,4 \%$ \\
Primorye & 343 & 120 & 463 & $0,8 \%$ \\
Magadan & 111 & 7 & 118 & $2,8 \%$ \\
\hline
\end{tabular}

Sources: F\&A, 2021; FFA, 2021.

In terms of enterprises number in the industry, Sakhalin (25.1\% of the total) and Kamchatka $(24.8 \%)$ occupy the first positions. There are 67 fish hatcheries operating in the Far East, of which 44 are located in Sakhalin, 10 in Khabarovsk, 5 in Kamchatka, 4 in Primorye, and 4 in Magadan. Both the enterprises number in the industry and their share in the total number of enterprises indicate the relative specialization of Sakhalin and Kamchatka in the fishing industry. In other districts, this specialization is not so pronounced, since it is eroded by other spheres of activity.

Retrospective analysis demonstrates a trend towards a steady decline in number of fishing enterprises, as well as a slight increase in number of aquaculture enterprises (Table 2).

Table 2.

Dynamics of the fishing and aquaculture enterprises number in the Far East of Russia, 2010-2019

\begin{tabular}{lccccccc}
\hline Indicators & $\mathbf{2 0 1 0}$ & $\mathbf{2 0 1 2}$ & $\mathbf{2 0 1 4}$ & $\mathbf{2 0 1 6}$ & $\mathbf{2 0 1 8}$ & $\mathbf{2 0 1 9}$ & $\begin{array}{l}\mathbf{2 0 1 9} \text { to } \\
\mathbf{2 0 1 0}\end{array}$ \\
\hline $\begin{array}{l}\text { Number of fishing } \\
\text { enterprises, units }\end{array}$ & 3060 & 2715 & 2685 & 2701 & 2683 & 2560 & $83,7 \%$ \\
$\begin{array}{l}\text { Number of aquaculture } \\
\text { enterprises, units }\end{array}$ & 191 & 182 & 204 & 262 & 213 & 225 & $117,8 \%$ \\
$\begin{array}{l}\text { Total number of } \\
\text { enterprises, units }\end{array}$ & 3251 & 2897 & 2889 & 2963 & 2896 & 2785 & $85,7 \%$ \\
$\begin{array}{l}\text { Volume of fish production } \\
\text { by enterprises, thousand }\end{array}$ & 1972 & 2911 & 2073 & 3244 & 3613 & 3537 & $179,4 \%$ \\
\hline \begin{tabular}{l} 
tons \\
\hline
\end{tabular}
\end{tabular}

Sources: F\&A, 2021; FFA, 2021.

The number of enterprises decreased in all catch areas, with the exception of Khabarovsk and Sakhalin. Traditionally, the enterprises number in the fishing industry and their most important indicators are influenced by a large number of factors. Biological, economic, law, institutional, conjuncture factors affect the fishing industry at the same time and are considered in their mutual connection (Glubokovsky et al, 2018). During the period under consideration, there is no significant correlation between the enterprises number and catch volume. The change in the enterprises number was mainly due to the increasing intra-industry competition in the context of foreign policy pressure on Russian exporters and price pressure from fish buyers. Not all enterprises can withstand the competitive pressure, organizational problems, imperfect legislation, influence of the shadow economy, etc.

The FER's fishing industry enterprises employ 30.9 thousand people. In relative terms, this figure is small - only $0.77 \%$ in the overall structure of the employed people. However, if we consider the industry from the standpoint of a cluster approach, we need to add to them those who are employed in industry education, industry science, administrative regulation, ship repair, instrument and mechanical engineering, retail trade in fish products, coastal processing industry and other related areas. In total, the complex of organizations related to resource provision, harvesting, processing and fish products sale forms a significant for the economy and labor market fishery cluster - multifunctional, 
segmented and multi-level.

Analysis of employment problems in the industry (including catching and processing) for 20102019 displays large amplitude of fluctuations in employees' number over the years. In particular, in 2010-2014 there was a sharp decrease - by $31 \%$ and in 2014-2019 there was a sharp increase - by $48 \%$ (Table 3 ).

Table 3.

Dynamics in number of fishing and aquaculture enterprises in the Far East of Russia, 2010-2019

\begin{tabular}{lcccccccc}
\hline Indicators & $\mathbf{2 0 1 0}$ & $\mathbf{2 0 1 2}$ & $\mathbf{2 0 1 4}$ & $\mathbf{2 0 1 5}$ & $\mathbf{2 0 1 6}$ & $\mathbf{2 0 1 8}$ & $\mathbf{2 0 1 9}$ & $\begin{array}{l}\mathbf{2 0 1 9} \text { to } \\
\mathbf{2 0 1 0}\end{array}$ \\
\hline $\begin{array}{l}\text { Volume of fish } \\
\text { production by } \\
\text { enterprises, thousand } \\
\text { tons }\end{array}$ & 1972 & 2911 & 2073 & 2963 & 3244 & 3613 & 3537 & $179,4 \%$ \\
$\begin{array}{l}\text { Number of fishing } \\
\text { workers, people }\end{array}$ & 30313 & 23372 & 20949 & 21396 & 22559 & 31681 & 30973 & $102,2 \%$ \\
$\begin{array}{l}\text { Number of aquaculture } \\
\text { workers, people }\end{array}$ & 2146 & 1705 & 1484 & 2542 & 1549 & 1521 & 1576 & $73,4 \%$ \\
$\begin{array}{l}\text { Total number of } \\
\text { employees, people }\end{array}$ & 32459 & 25077 & 22433 & 23938 & 24108 & 33202 & 32549 & $100,3 \%$ \\
$\begin{array}{l}\text { Production per } \\
\text { employee, tons }\end{array}$ & 60,8 & 116,1 & 92,4 & 123,8 & 134,6 & 108,8 & 108,7 & $178,9 \%$ \\
\hline Sources: $F A, 2021 ; F F A$ & 2021. & & & & & & & \\
\hline
\end{tabular}

Sources: F\&A, 2021; FFA, 2021.

As a result, the number of people employed in the industry has remained almost unchanged over the current decade. There are several reasons for these dynamics, all of them are predominantly organizational and institutional and are to a lesser extent related to the catch volumes dynamics. The enterprises' attempts to survive under the complicated foreign policy, highly competitive environment and insufficient government support led to measures to reduce direct production costs, which negatively affected wages, stability at enterprises and social programs in the industry.

Dissatisfaction with wages, dependence of wages and bonuses on market conjuncture are traditional factors of stuff turnover in the regional fishing industry. For a long time, the official wages in the fishing industry were low compared to other sectors of the economy. The situation has improved a lot lately. According to Federal Agency for Fisheries, in 2020 the average salary of workers in fishing industry was about $\$ 1,250$ per month, which is $10-12 \%$ more than in other extractive industries and 7-10\% more than in the processing industries (F\&A, 2021; FFA, 2021). Nevertheless, we should admit that wages are distributed unevenly across the catch areas, the type of work, work experience, professional \& qualification level, etc. Often, ordinary workers on fishing vessels receive only half of the indicated average salary. Taking this into account, fish products production increases faster than labor costs. On the one hand, this leads to cost savings at enterprises, which is estimated at $7 \%$ of revenue (Volodina, 2019). On the other hand, this increases stuff turnover in the industry, worsens the human capital quality, reduces motivation and workers loyalty, and also, importantly, contributes to emergence of informal, shadow payment schemes, unrecorded backstreet jobs, illegal fisheries and other negative consequences for regional economy.

Speaking about employment in the fishing industry, we should highlight difficult working conditions in it and long cycle of technology renewal on ships. Up to $40 \%$ of males employed in the industry and up to $30 \%$ of females work in harmful and / or dangerous working conditions. At the same time, $20 \%$ of all employed people, regardless of gender, do hard work (F\&A, 2021). Significant improvement of working conditions at sea, ensuring safe life and work for fishermen are among the priorities of Russian Government.

As for aquaculture, in Table 3 we can see a negative trend in number of people employed in this segment of the fishing industry. Only in 2015 there was a surge in number of workers. This growth was facilitated by passing in 2014 a federal law «On aquaculture (fish farming)» which was started in 2015. «Under the mechanism of distributing fish breeding areas for Far East aquaculture development, more than 30 thousand hectares of water area have been assigned for use; another 46 thousand hectares have been prepared for sale through the auction 
system». As a result, in 2016 the industry enterprises turnover amounted to 291 billion rubles, which is $11 \%$ more than in 2015 . The fisheries' contribution to GDP was 218 billion rubles, which is $6.6 \%$ higher than in 2015 . However, after 2015, fish farming was unable to quickly overcome the technological backwardness of production, solve organizational and institutional problems, as well as withstand the market decline in Russian exports. In this regard, the number of people employed in fish farming returned to the level of 2013-2014.
As we noted above, fish production annual volume are growing in the FER year after year. For 2010-2019, it increased by 1.5 million tons, or almost $80 \%$. Average annual growth rate of fish catch was $8.9 \%$ for the period. Despite some volatility and a slowdown in the growth of catch volumes by the end of the current decade (Figure 2), Russian side predicts its world leadership in terms of catch growth rates by 2030 . To achieve this goal, the main focus is on both aquaculture (fish farming) development and efficiency \& ecological cleanliness growth in the fishing industry in the Far East (FFA, 2021).

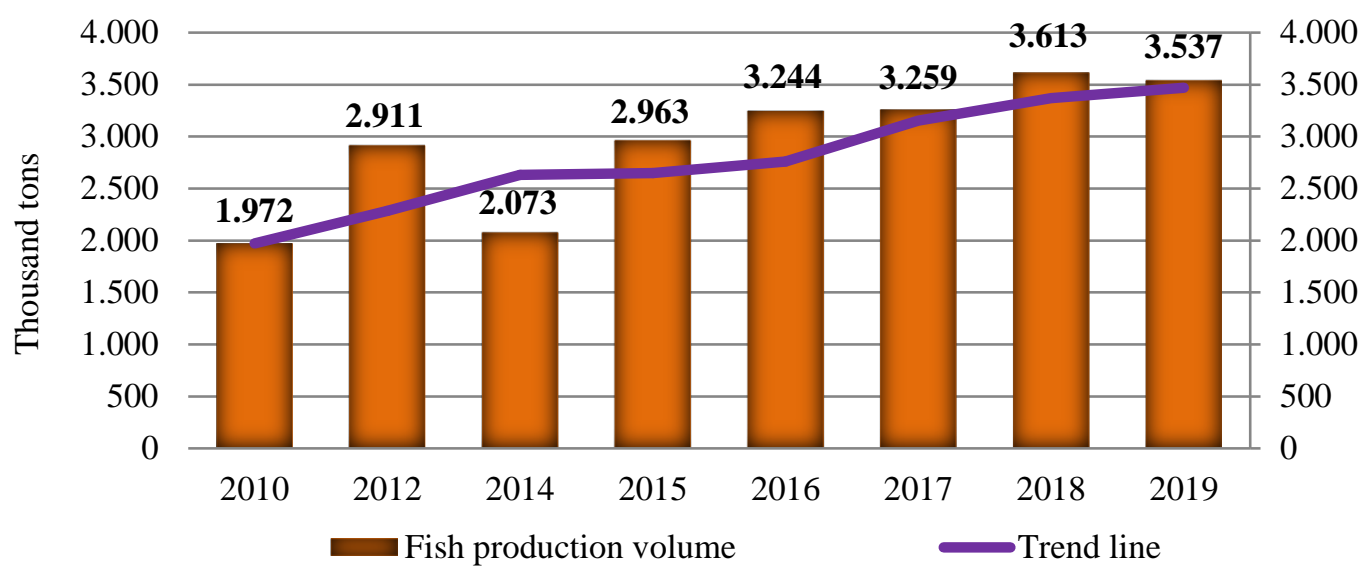

Figure 2. Dynamics of fish catch volumes in the Far East of Russia, 2010-2019. Sources: F\&A, 2021; FFA, 2021.

Fish production is distributed according to catch areas in the following order. Kamchatka enterprises caught 1,580 thousand tons of fish in 2019 , which is $45 \%$ of the total catch in the Far East, Primorye - 757 thousand tons (21\%), Sakhalin -656 thousand tons (19\%), Khabarovsk - 415 thousand tons (12\%) and Magadan - 100 thousand tons (3\%) (F\&A, 2021; FFA, 2021). In general over the decade, the contribution of each region is unequal. Therefore, for 2016-2019 the fish catch in Kamchatka increased by 456.2 tons, while in other areas it decreased for various reasons. Thus, Kamchatka makes a maximum contribution to the catch volume growth of far eastern fish (Figure 3).

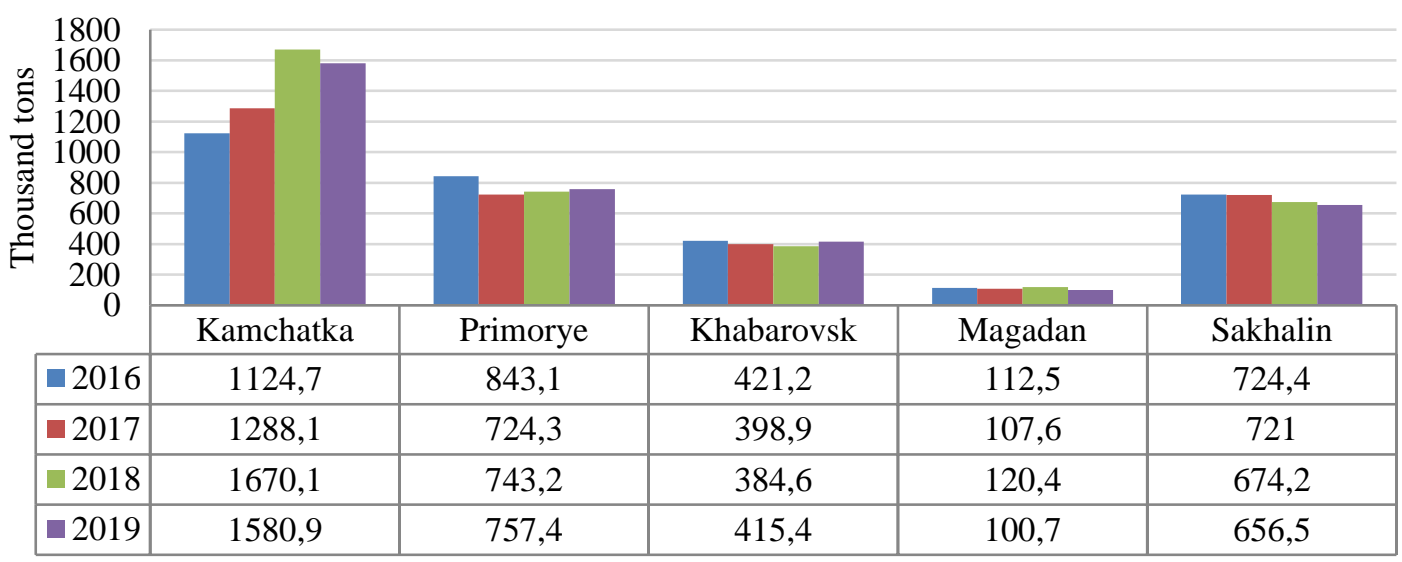

Figure 3. Fish catch structure by catch areas in the Far East of Russia, 2016-2019. Sources: F\&A, 2021; FFA, 2021. 


\section{$\frac{\text { AMAZONDA }}{\text { Mnvestiga }}$}

Fish and marine invertebrates are traditional catched organisms. The dominant fish species are pollock, herring, cod, flounder, saury, salmon (pink salmon, chum salmon and sockeye salmon), and mackerel. The dominant marine invertebrates are squid, crabs, shrimps,

Table 4.

Catch volumes of some marine biological resources in the Far East of Russia, 2010-2019, thousand tons

\begin{tabular}{llllll}
\hline $\begin{array}{l}\text { Catched } \\
\text { organisms }\end{array}$ & $\mathbf{2 0 1 0}$ & $\mathbf{2 0 1 5}$ & $\mathbf{2 0 1 9}$ & $\begin{array}{l}\mathbf{2 0 1 9} \text { to } \\
\mathbf{2 0 1 0}\end{array}$ & $\begin{array}{l}\mathbf{2 0 1 9} \text { to } \\
\mathbf{2 0 1 0 ,} \%\end{array}$ \\
\hline Pollock & 1579,8 & 1623,6 & 1733,1 & 153,3 & 1,10 \\
Herring & 216,0 & 293,5 & 383,5 & 167,5 & 1,78 \\
Cod & 72,6 & 78,9 & 155,6 & 83,0 & 2,14 \\
Flounder & 77,5 & 80,3 & 86,4 & 9,0 & 1,12 \\
Saury & 57,5 & 63,2 & 2,4 & $-55,1$ & 0,04 \\
Salmon & 471,2 & 372,7 & 498,0 & 26,8 & 1,06 \\
Crabs & 36,0 & 49,9 & 71,9 & 35,9 & 2,00 \\
Squid & 64,3 & 53,8 & 99,0 & 34,7 & 1,54 \\
\hline
\end{tabular}

Sources: F\&A, 2021; FFA, 2021.

Among the fish species that are being caught in the Far East, pollock has the highest weight. It a tasty and healthy fish, which is one of the leanest rich in vitamins and minerals fish, therefore it is actively used in daily and dietary nutrition. From an economic point of view, this is one of the cheapest fish due to its abundance, rapid weight growth of mature individuals and a large habitation area. In Russia, pollock is caught exclusively in the Far East; $62.3 \%$ is being caught in the Okhotsk Sea. In live weight, pollock occupies $53.5 \%$ of all fish caught in Russia and $50.0 \%$ of all caught marine biological resources (FFA, 2021). Over the past decade, the pollock catch has been steadily increasing. The annual catch in 2019 increased compared to 2010 by 152 thousand tons, or almost $10 \%$.

In 2020, according to preliminary data, the pollock catch increased by about $4-5 \%$ compared to 2019. However, already in 2021, the catch dropped sharply due to sales problems. According to Federal Agency for Fisheries of Russian Federation, 1.24 million tons of pollock had been caught in the Far East since the beginning of the year by August 2021. This is echinoderms, scallops, and trumpeters. Algae harvesting is also common. These types of biological resources are very popular with consumers all over the world. The weight values of some main objects of catching in dynamics are presented in Table 4.
$16 \%$ less than in the same period in 2020. Russia sends a large share of pollock to export; and 60\% of the export go to China. In turn, processed pollock fillets are bought from China by European countries and the United States. Today, China is closing borders for Russian fish masking it by non-proliferation of coronavirus. This creates certain difficulties for Russian fishermen under storing, transporting, registering cargo and selling fish. The situation with pollock demonstrates, on the one hand, an urgent need to diversify the sales markets for Russian fish, including domestic ones, on the other hand, a necessity to actively develop the national processing industries. China is also looking for the best ways to interact with Russia in difficult epidemiological and economic conditions (Krasova \& Bogach, 2017; Zhang et al, 2021).

Salmon and Pacific herring are the next weight giants after pollock in the FER's catches. They occupy $14.9 \%$ and $11.7 \%$ respectively in the total weight of the catches. The general structure of fish catch in the Far East by species is shown in Figure 4, a. 


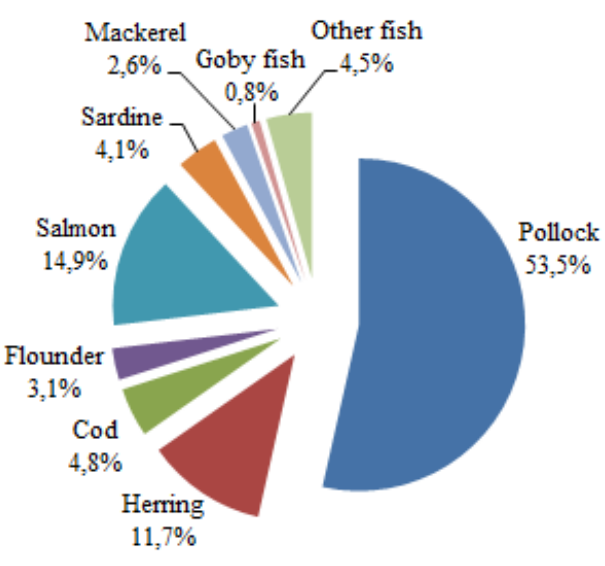

(a)

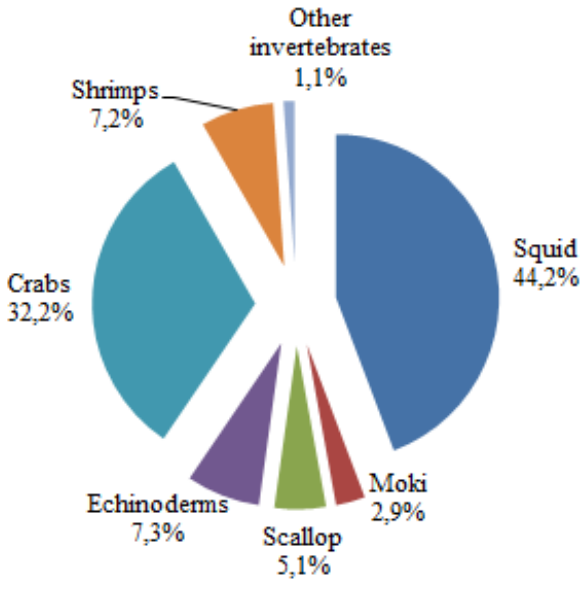

(b)

Figure 4. Fish catch structure by species in the Far East of Russia, 2019 (a). Marine invertebrates catch structure by species in the Far East of Russia, 2019 (b). Sources: FFA, 2021.

The species structure of fish catch is rather stable year after year. Shares of main species have been slightly decreasing over the past decade: pollock - from $61 \%$ to $57 \%$, salmon - from $18 \%$ to $17 \%$ and flounder - from $4 \%$ to $3 \%$. At the same time, the share of herring has increased from $8 \%$ to $13 \%$ and $\operatorname{cod}-$ from $3 \%$ to $5 \%$.

Total volume of marine invertebrates caught in 2019 is almost 222 thousand tons. The catch structure of marine invertebrates is quite stable. In particular, share of squid and crabs remained unchanged at the level of $44 \%$ and $32 \%$, respectively, compared to previous years (Figure $3, b)$.

Among marine invertebrates squid is the largest product in weight. This fortified high-protein product provides up to $90 \%$ of the required daily protein intake. In 2019, near 98 thousand tons, or $44.2 \%$ of all marine invertebrates, that were caught in the Far East. According to estimates, in 2020 its catch increased by 1.5 times: almost 120 thousand tons have been caught over 9 months. This increase is due to biological reasons: the high survival rate of Commander Squid of the 2018 generation led to its high abundance in 2020 (FFA, 2021).

An important product of the Far Eastern fishing industry is live, fresh and chilled fish, which in weight terms accounts for $21.3 \%$ of the total catch. Sakhalin is the leader in the production of fresh fish among all catch areas. It accounts for about $43 \%$ of all fresh fish produced in Russia
(827 thousand tons in 2019) and 53\% of fresh fish produced in the Far East (681 thousand tons in 2019). The shares of Kamchatka are 17\% and $20 \%$ respectively, Magadan $-10 \%$ and $12 \%$, Primorye $-8 \%$ and $10 \%$.

The fresh fish production in the Far East has grown up until 2013. Since 2013 a sharp tendency of production decline has formed: in 2019, in Sakhalin the decline was 167 thousand tons, or $31 \%$ of the 2010 level, in Kamchatka 55 thousand tons, or $28.6 \%$ of the 2010 level. Fresh fish production in Magadan remains almost unchanged on the 2010 level; in Primorye it increased by 8.5 thousand tons, in Khabarovsk - by 18.8 thousand tons.

Production volume of processed fish, as well as canned fish products in the Far East in 2019 amounted to 2.6 million tons. The analysis shows an upward trend in processed fish production for $2010-2019$ by 420 thousand tons, or $19.3 \%$. The leader in fish processing in the Far East is Kamchatka, which produces $42 \%$ of these products in the region and $26 \%$ in Russia as a whole. In 2019 the enterprises of Kamchatka produced 1,086 thousand tons, which is $48 \%$ more than in 2012. Primorye accounts for $25.7 \%$ in fish processing volume in the Far East and $16 \%$ in the same volume in Russia, Sakhalin $16.6 \%$ and $10 \%$ respectively.

Figure 5 clearly shows the different trends in the production of fresh and processed fish. 

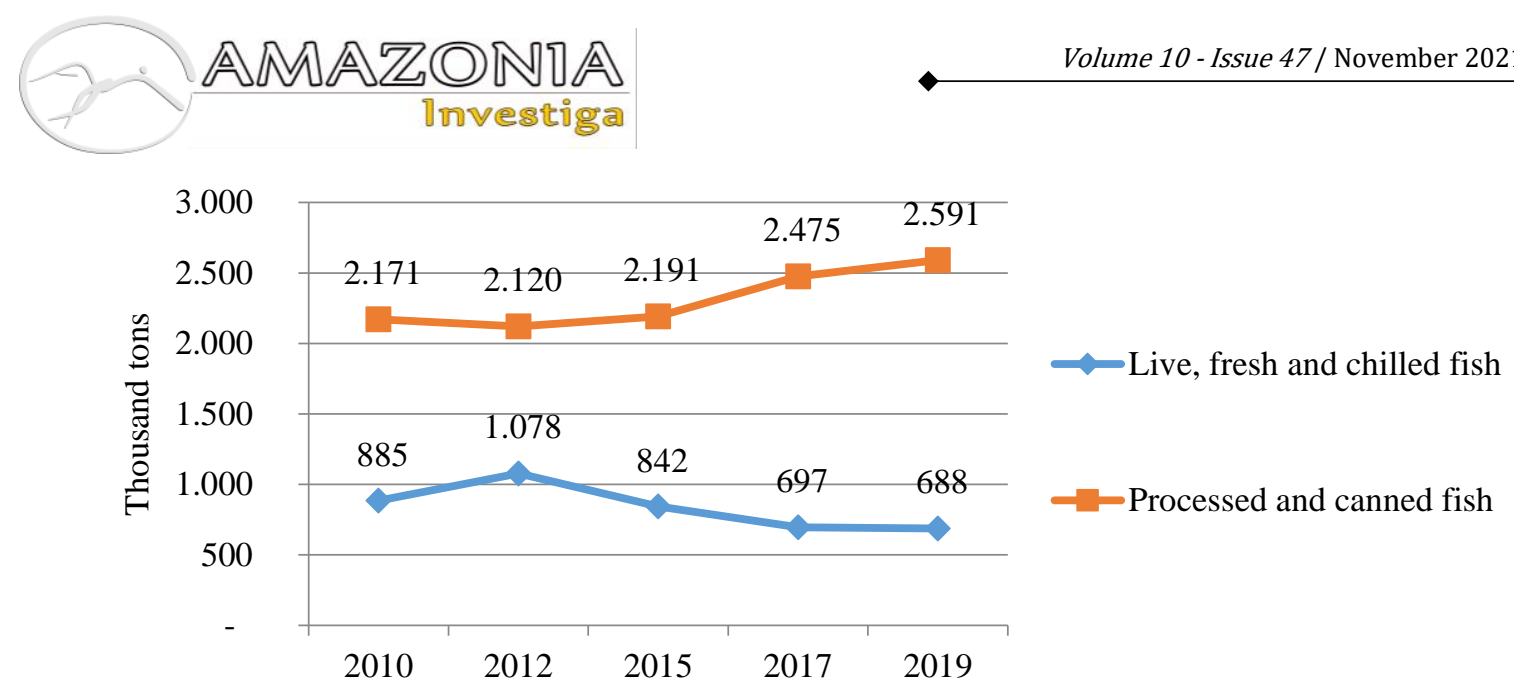

Figure 5. Dynamics of fresh and processed fish production in the Far East of Russia, 2010-2019. Sources: F\&A, 2021; FFA, 2021.

Despite the growth in fish catch and fish production, we can observe a tendency to decrease the fish products consumption by the population in Russian Far East. In 2013, fish consumption was $30.9 \mathrm{~kg}$ per person, and by 2018 , it had decreased to $26 \mathrm{~kg}$. Consumption is not the same in all regions, in Kamchatka and Khabarovsk - $28.8 \mathrm{~kg}$ per year, which is higher than the average for FER, with the recommended $22 \mathrm{~kg}$ per person per year.
The amount of fish consumed varies greatly depending on the type of residence place (city, village). In 2015, urban consumption was $29.5 \mathrm{~kg}$, and by 2019, it had dropped to $19 \mathrm{~kg}$. Fish consumption by the rural population has decreased from 29.8 to $27.8 \mathrm{~kg}$. In 2017 , it dropped even lower - to $16.6 \mathrm{~kg}$, but then increased to $27.8 \mathrm{~kg}$ (Figure $6)$.

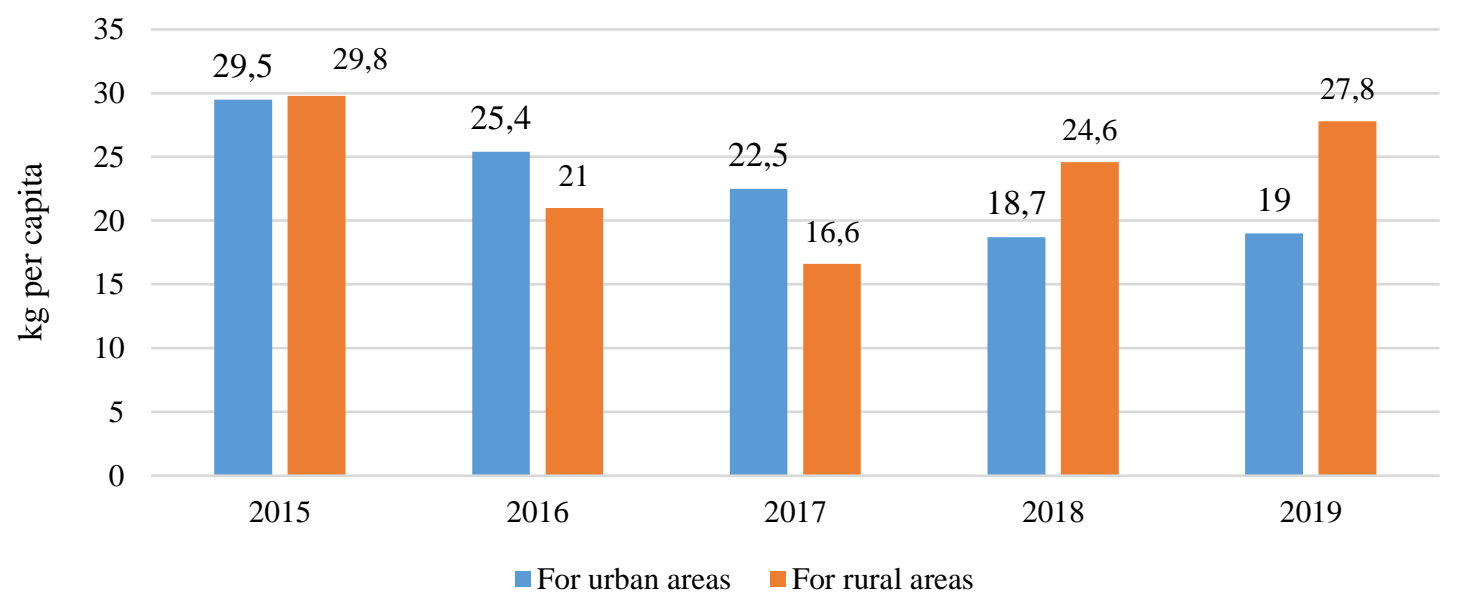

Figure 6. Average annual fish consumption in the Far East of Russia, 2015-2019. Sources: F\&A, 2021; FFA, 2021.

The decline in fish consumption by the population is a negative trend not only for the Far East, but also for Russia as a whole. For comparison: in China, the average annual fish consumption per capita is $48 \mathrm{~kg}$ per year. In Republic of Korea citizens eat $59.9 \mathrm{~kg}$ of fish with catch volumes comparable to Russian ones (3623.7 thousand tons), in Japan - $48 \mathrm{~kg}$ with catch volume of 4239.8 thousand tons (Ryzhkova, \& Kruchinina, 2020; Szymanska, 2020). The main reason for such situation is rather high prices for fish and seafood, a relatively low paying capacity of Russian population and a high share of food expenses in total income. The orientation of fish producers to the external markets creates a completely paradoxical situation in the Far East when significant production volumes is accompanied by the poorly developed internal distribution networks. As a result, we can see a dynamic rise in prices for fish products in the region. As you can see from Table 5, all fish products are becoming more expensive, and the prices for overwhelming majority of fish products are rising faster than the average consumer prices in the country. 
Table 5.

Average consumer prices for some fish products in the Far East of Russia, 2015-2019, rubles per kg.

\begin{tabular}{|c|c|c|c|c|c|c|}
\hline Product type & 2015 & 2017 & 2019 & $\begin{array}{l}2019 \text { to } \\
2015, \%\end{array}$ & $\begin{array}{l}\text { Average } \\
\text { annual } \\
\text { growth } \\
\text { rates for } \\
\text { 2015-2019 }\end{array}$ & $\begin{array}{l}\text { Higher than } \\
\text { the inflation } \\
\text { rate for the } \\
\text { period }\end{array}$ \\
\hline Live and chilled fish & 95 & 105 & 104 & 109,5 & $2,4 \%$ & $-1,4 \%$ \\
\hline $\begin{array}{l}\text { Salted, marinated, smoked } \\
\text { fish }\end{array}$ & 543 & 575 & 610 & 112,3 & $3,1 \%$ & $-0,7 \%$ \\
\hline $\begin{array}{l}\text { Salted and smoked fish } \\
\text { delicacies }\end{array}$ & 746 & 935 & 978 & 131,1 & $7,8 \%$ & $4,0 \%$ \\
\hline Salmon caviar & 2477 & 3048 & 2926 & 118,1 & $4,5 \%$ & $0,7 \%$ \\
\hline $\begin{array}{l}\text { Frozen cut fish (except for } \\
\text { salmon species) }\end{array}$ & 111 & 124 & 141 & 127,0 & $6,8 \%$ & $3,0 \%$ \\
\hline Chilled and frozen cut fish & 200 & 262 & 278 & 139,0 & $9,8 \%$ & $6,0 \%$ \\
\hline Frozen whole fish & 124 & 171 & 174 & 140,3 & $10,1 \%$ & $6,3 \%$ \\
\hline Fish fillet & 223 & 230 & 272 & 122,0 & $5,5 \%$ & $1,7 \%$ \\
\hline $\begin{array}{l}\text { Canned fish natural with } \\
\text { added oil }\end{array}$ & 93 & 126 & 124 & 133,3 & $8,3 \%$ & $4,5 \%$ \\
\hline
\end{tabular}

Sources: F\&A, 2021; FFA, 2021.

Both the rising prices and shortcomings in modern food culture, focused on fast and cheap junk food, do not contribute to demand growth for fish products. Despite the growth in retail sales of fish products at current prices, the dynamics expressed in comparable prices cannot be called increasing, since the sales growth rates fluctuate significantly. Moreover, although the volume of regional catch is increasing, the share of fish products in the total volume of retail sales does not increase (Table 6).

Table 6.

Retail sales of fish and seafood in the Far East of Russia, 2015-2019

\begin{tabular}{|c|c|c|c|c|c|c|}
\hline Indicators & 2015 & 2016 & 2017 & 2018 & 2019 & $\begin{array}{l}2019 \text { to } \\
2015\end{array}$ \\
\hline $\begin{array}{l}\text { Retail sales of fish, crustaceans and } \\
\text { molluscs in current prices, million } \\
\text { rubles }\end{array}$ & 969,2 & 1030,8 & 1164,1 & 1285,6 & 1296,8 & $133,8 \%$ \\
\hline $\begin{array}{l}\text { Retail sales of canned fish and seafood } \\
\text { in current prices, million rubles }\end{array}$ & 286,4 & 322,9 & 371,3 & 398,6 & 397,6 & $138,8 \%$ \\
\hline $\begin{array}{l}\text { Retail sales of fish, crustaceans and } \\
\text { molluscs in comparable prices, } \% \text { to the } \\
\text { previous year }\end{array}$ & 95,5 & 96,1 & 102 & 106,1 & 39,9 & $\begin{array}{l}-55,6 \\
\text { p.p. }\end{array}$ \\
\hline $\begin{array}{l}\text { Retail sales of canned fish and seafood, } \\
\text { in constant prices, } \% \text { to the previous } \\
\text { year }\end{array}$ & 98,4 & 91,7 & 98,1 & 103,4 & 96,8 & $\begin{array}{l}-1,6 \\
\text { p.p. }\end{array}$ \\
\hline $\begin{array}{l}\text { Share of fish, crustaceans and molluscs } \\
\text { in the retail turnover of food } \\
\text { products, } \%\end{array}$ & 3,1 & 3,2 & 3,5 & 3,8 & 3,5 & $\begin{array}{l}+0,4 \\
\text { п.п. }\end{array}$ \\
\hline
\end{tabular}

Sources: F\&A, 2021; FFA, 2021.

The Russian government plans to partially solve the problem of fish prices growth by developing aquaculture (fish farming), but its share in the country's fisheries is still unjustifiably small. Today aquaculture is a strategically important branch of the national economy, engaged in fishing industry in order to increase and improve the quality of fish resources in the country.
Cultivation of fish fry and its release into the natural habitat are carried out by fish hatcheries. Unfortunately, at present we can observe tendencies of growing costs for aquatic biological resources reproduction together with a relatively stable release of cultivated juveniles (Figure 7). 

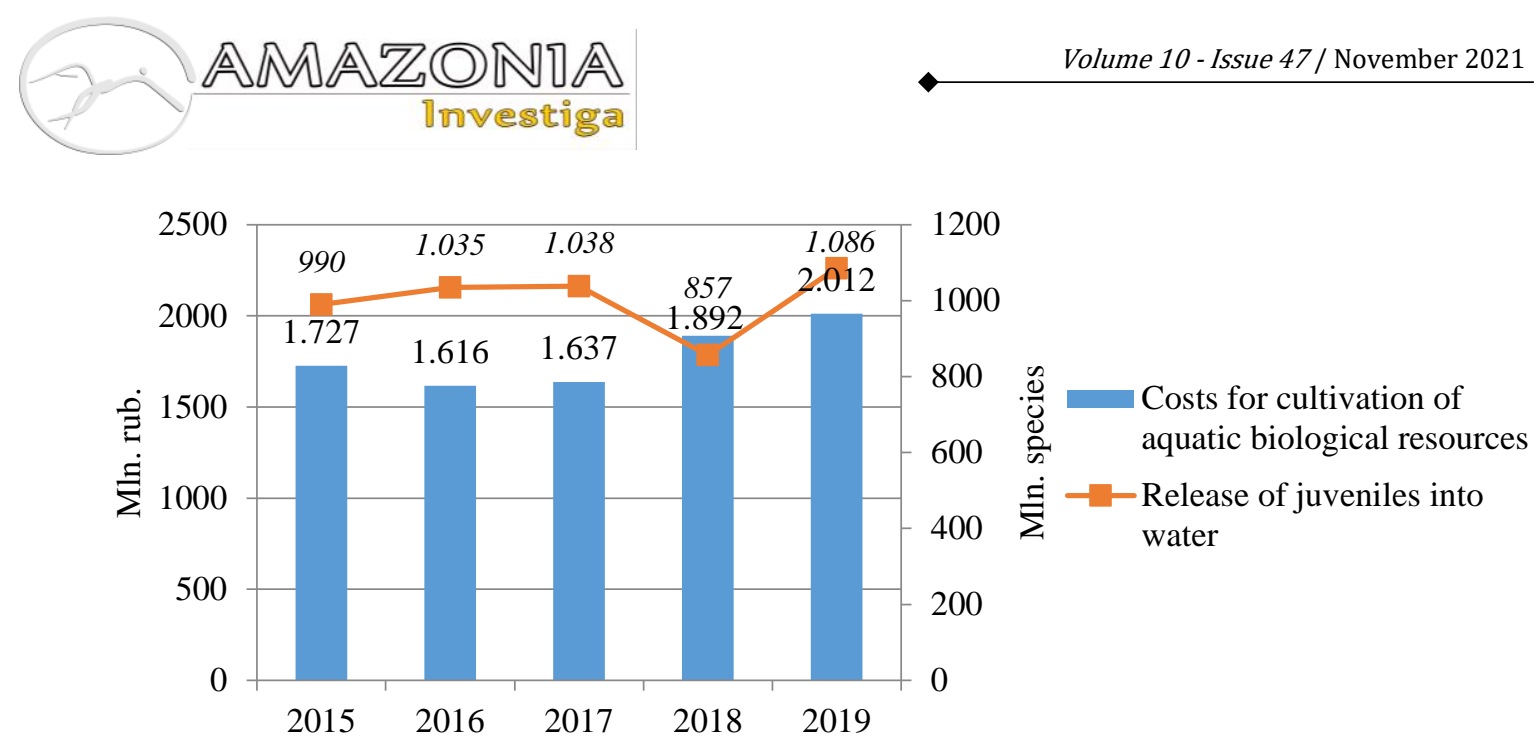

Figure 7. Costs for cultivation of aquatic biological resources and release of juveniles into water, 2015-2019. Sources: F\&A, 2021; FFA, 2021.

In the long term, Russian aquaculture plans to develop on an innovative basis under the effective use of its own and foreign scientific and technical R\&D and advanced experience. Only in Primorye, in the very south of the Far East, conditions for mariculture cultivation on 50 thousand hectares of seawater area so that to get thousands tons of products have already made. Aquaculture as an industry includes both sea pasturing as well as pond and industrial fish farming (FFA, 2021; Kalinina et al, 2018). It is assumed that in the future, the cost of fish farming will continue to grow, primarily due to investments that will be spent on purchasing land, equipment, technologies, feed, etc. Investment attractiveness and the volume of financial investments in marine aquaculture facilities primarily depend on the appropriate organizational and institutional support formation, simplification of allocating lands conditions for fisheries (Logunova et al, 2021).

The Far East fishing industry is an exportoriented sector of Russia: about 50\% of fish produced, mainly frozen fish, is exported. In 2020, the export value was estimated at 1.6 million tons worth 3.47 billion dollars. By now, a long-term trend of increasing fish exports both in weight and value terms has emerged. Despite the high volatility of the export growth for 20102019 the annual export value of far eastern fish increased by $\$ 1,692.9$ million or almost doubled (Figure 8).

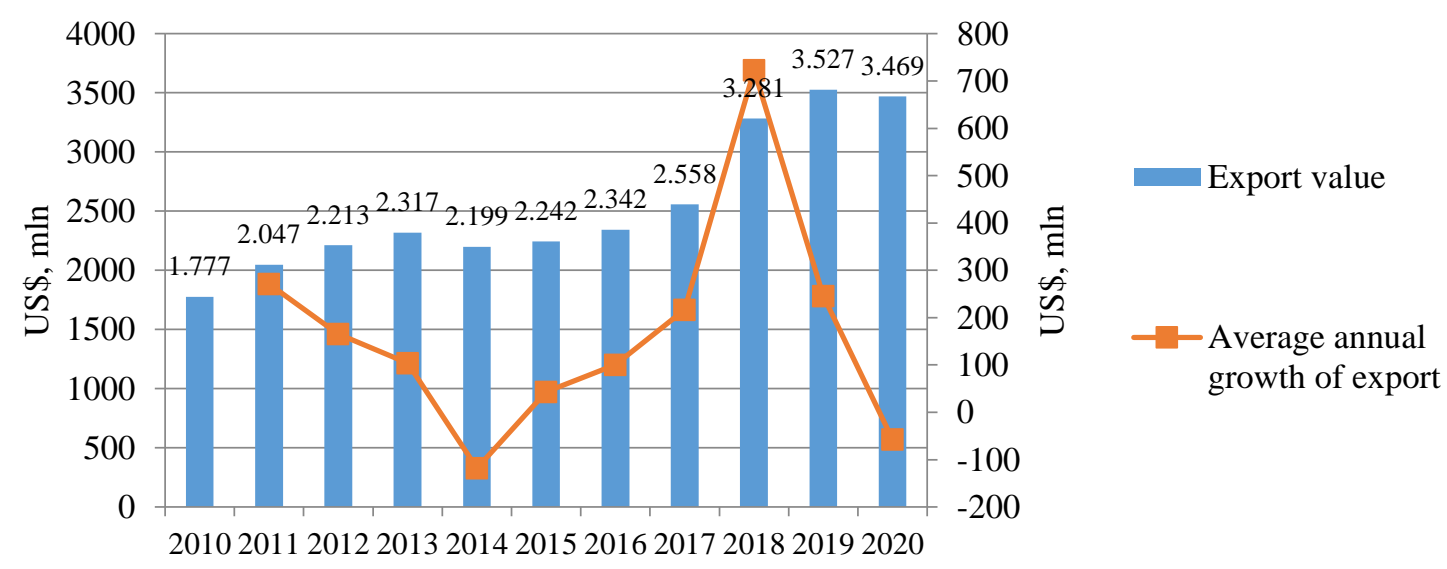

Figure 8. Fish export value dynamics in the Far East of Russia, 2010-2020. Sources: F\&A, 2021; FFA, 2021.

The main importing countries for FER's export products are Republic of Korea, which receives $38 \%$ of far eastern fish, Japan with $36 \%$, and China with $26 \%$. About $60-70 \%$ of production is transported through the ports of Primorye, from where it is sent to ports of Qingdao, Busan, and then to the markets of Japan, USA and Europe. In 2020, a decrease in export in weight terms was recorded in the direction of China ( -1042.5 tons), the Republic of Korea (-129.6 tons) and Japan 
(-52.1 tons). This decrease is due to both a drop in global demand caused by pandemic and the unwillingness to diversify the country's export structure because of strong dependence on consumers in Asian countries. An important factor aggravating the problems of selling fish products in the foreign market is the reduced demand in the domestic market
(Paptsov et al, 2021).

The strategic importance of the FER's fishing industry determines positive dynamics of the industry investments. Since 2014, the volume of capital investments has an upward trend: over the period 2010-2019, investments have increased by more than 13 times (Figure 9).

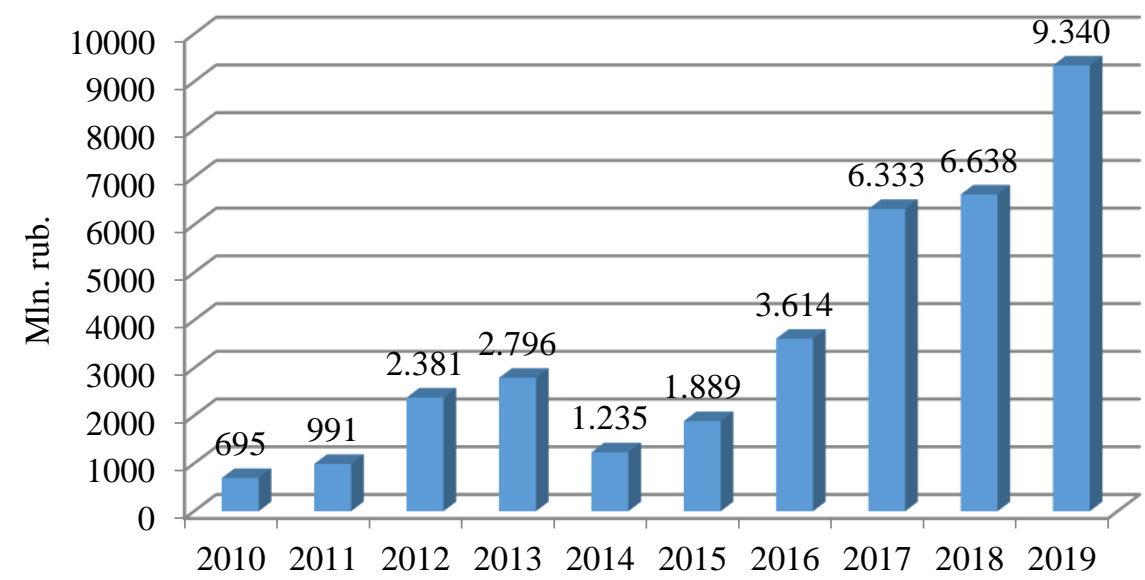

Figure 9. Investments in fixed assets of the Far East fisheries, 2010-2019. Sources: F\&A, 2021; FFA, 2021.

Experts believe that although the trend is positive, the volume of investments in the industry is not sufficient to form a technologically and economically sustainable cluster with diversified production of highavailability fish products, with wide internal distribution network and diversified exports. In addition, they are not enough to achieve the industry development targets, defined in government documents. For a long time, the industry had a shortage of investment resources, and a low start effect has occurred in the current decade: investment growth seemed to be rather strong on the background of chronic underfunding in the past (Mnatsakanyan \& Kharin, 2017; Glubokovsky et al, 2018).

At present, Russian government keeps focus on the formation of various sources of large-scale investment in the fishing industry to overcome technological backwardness and to recover the overall financial position of fishing and aquaculture enterprises. Under this course, FER plans to develop both national and joint investment projects with other countries. The construction of a modern fish processing plant by Dobroflot Company in Primorye can be regarded as a fresh example of the national investment projects implementation. Amount of investment was 1.7 billion rubles. Among other countries, Republic of Korea and Japan are still the main potential partners for FER's fishing industry development. The project of Korean industrial group Daelim Corporation looks promising for construction of a fish storage complex and a grain terminal in the Primorye with a total cost of 80-100 million dollars. The Japanese company Saraya also plans to implement a project to create a fish processing plant in the Primorye.

\section{Conclusions}

The research made it possible to draw the following conclusions.

The fishing industry development in the Russian Far East is characterized by a number of different and multidirectional trends. The key trends that determine prospects of the industry further development include the following:

- decrease in number of fishing enterprises and increase in number of aquaculture enterprises;

- volatility of employees number in the fishing industry, decrease in employees number in aquaculture. Taking into account the growing catch, this leads to a formal increase in output per worker in the industry;

- stable growth in catch of fish and marine biological resources, although we noted some volatility of catch volumes across the catch regions;

- stable structure of catches by types of 


\section{AMAZONZA \\ 1ึvestiำ}

biological resources. Pollock, herring and salmon still dominate in the fish catch structure. Squid and crabs take a lot of weight in the structure of marine invertebrates catch;

- processed and canned fish predominance of in the total structure of fish products produced. At the same time, fresh, live and chilled fish retains great importance;

- decrease in fish consumption by the population on the background of significant increase in prices for fish products on the FER's domestic market;

- growth of fish products retail sales at current prices together with conserving a persistently low share of fish products in the retail turnover of food products;

- progressive development of aquaculture, accompanied by increase in costs and a stable amount of released juveniles;

- steady growth of export value, mainly to the countries of Northeast Asia;

- increment of investments in fixed assets of the industry, gradual implementation of projects in the field of fisheries and aquaculture.

In addition, during the research the following important problems were revealed:

- dependence of the FER'S fishing industry (by a number of indicators) on the world market situation;

- insufficient development of the regional domestic market and internal distribution networks;

- excessive growth in prices for fish products in the domestic market. The prices growth is not supported by increasing the demand or consumption;

- rather low degree of fish products processing;

- dependence of fish export on Asian countries, primarily China, Republic of Korea and Japan; low country and product diversification of the export;

- insufficiency of investment in the industry fixed assets for strategic development and technological renewal.

The trends and problems designated under the research should become a basis for the further development and improvement of the FER's fishing industry.

\section{Bibliographic references}

F\&A (2021). Fisheries and Aquaculture. Federal
State Statistics Service Website. https://rosstat.gov.ru/folder/14305

FAO (2021). FAO Yearbook of Fishery and Aquaculture Statistics 2018. Food and Agriculture Organization of the United Nations. Rome, Italy. http://www.fao.org/fishery/static/Yearbook/ YB2018_USBcard/booklet/web_CB1213T.p df

FFA (2021). Industry in statistics. Federal Fisheries Agency Website. https://fish.gov.ru/category/otrasl-v-tsifrakh/

Fisenko, A.I., \& Saltykov, M.A. (2020). Fisheries cluster: coefficient methodological approach to assessing the potential and the possibility of formation in the Far East of Russia. Marine Intellectual Technologies, 1-2(47), 249-256. DOI: 10.37220/MIT.2020.47.1.084

Glubokovsky, M.K., Glubokov, A.I., \& Sinyakov, S.A. (2018). Prospects for the Development of the Russian Fisheries Complex. Publ. House Creative economy, Moscow, Russia. $190 \quad$ p. https://www.elibrary.ru/item.asp?id=349428 79

Kalinina, L., Zelenskaya, I., \& Trufanova, S. (2018). Prospects of development of aquaculture in Russia and its regions. Proceedings of the 1st International Symposium on Water Resource and Environmental Management (WREM 2018). Publ. by E3S Web of Conferences, 81, article 01008

Kim, H.S., \& Saltykov, M.A. (2020). Trade relations between Russia and the Republic of Korea at the stage of signing the free trade agreement: problems of Korean entrepreneurs. Customs Policy of Russia in the Far East, 1(90), 24-38. DOI: 10.24866 / 1815-0683 / 2020-1 / 24-38

Krasova, E.V., \& Bogach, A.S. (2017). Modern trends in the development of the Russian export of food products and agricultural raw materials. Theoretical and Applied Economics, 4, 49-58.

Lisienko, S.V., \& Ivanko, N.S. (2020). Optimization of fishing activities in multispecies fishing systems - fishing zones in their static state, taking into account biotechnological dualism (using the example of the North Kuril zone of the Far Eastern fisheries basin). Marine Intelligent Technologies, 4-1(50), 231-238. DOI: 10.37220/MIT.2020.50.4.032

Logunova, N., Glechikova, T., \& Kotenev, A. (2021). Investment attractiveness of the area for marine farming and marine aquaculture target species. Transportation Research 
Procedia, 54, 76-83. DOI: 10.1016/j.trpro.2021.02.051

Malenkov, Yu.A., \& Dreving, S.R. (2009). Development of strategies for the development of industries, economic complexes and clusters (using the example of the fisheries complex of the Kamchatka Territory). Publ. House Prospect, Moscow, Russia. 304 p.

Mnatsakanyan, A.G., \& Kharin, A.G. (2017). Investments in the fishing industry in Russia: analysis, trends and prospects. The Fisheries Journal, 3, 52-56

Osipov, V.A., \& Krasova, E.V. (2017). Modern specialization of industry in cities of the Russian Far East: innovation factor of dynamics. Espacios, 38(62), 29.

Paptsov, A.G., Shelamova, N.A., \& Avarskii, N.D. (2021). Challenges and prospects of the fishing export potential development in the Far East. Nexo Revista Cientifica, 34(2), 950-963

Pauly, D. (2008). Global fisheries: a brief review. Journal of Biological Research-Thessaloniki, 9, 3-9

Rousseau, Y., Watson, R.A., Blanchard, J.L., \& Fulton, E.A. (2019). Evolution of global marine fishing fleets and the response of fished resources. Proceedings of the National Academy of Sciences of the United States of America, 116(25), 12238-43

Ryzhkova, S.M., \& Kruchinina, V.M. (2020). Trends in the consumption of fish and fish products in Russia. Proceedings of the Voronezh State University of Engineering Technologies, 82, 2(84), 181-189. DOI: 10.20914/2310-1202-2020-2-181-189

Saltykov, M.A., \& Obraztsova, E.Yu. (2020). Evaluation of competition in the fishing industry of the Far Eastern Federal District based on the analysis of quotas. Bulletin of the Tomsk State University. Economy, 51, 88-109. DOI: $10.17223 / 19988648 / 51 / 5$

Saltykov, M.A., Stetsyuk, V.V., \& Pravikov, O.V. (2020). Evaluation of fishing industry clusterization in the Russian Far East within the context of integration with Asian-Pacific markets. Amazonia Investiga, 9(27), 518-535. DOI: 10.34069/AI/2020.27.03.56

Saltykov, M.A., \& Tkachenko, T.I. (2021). Multidimensional classification for systematization of fish processing equipment. IOP Conference Series: Earth and Environmental Science: International science and Technology Conference «Earth Science». IOP Publishing Ltd., p. 022087.
DOI: 10.1088/1755-1315/666/2/022087

Szymanska, J. (2020). Analysis of changes in the volume of fish production and consumption in the world - selected problems. Proceedings of the 35th International-BusinessInformation-Management-Association Conference (IBIMA), Seville, Spain, 197218 https://ibima.org/acceptedpaper/analysis-of-changes-in-the-volume-offish-production-and-consumption-in-theworld-selected-problems.

Terentyeva, T.V., Vasilenko, M.V., \& Titova, N.Y. (2019). Organizational and economic mechanism for sustainable development of fishing industry of the Primorye Territory: cluster approach. Dilemas Contemporaneos-Educacion Politica Y Valores, 6, Article 132

Volodina, S.G. (2019). Key directions for reducing direct costs (on the example of the fishing industry) Azimuth of Scientific Research: Economics and Administration, 8, 4(29), 115-117. DOI: 10.26140/anie-20190804-0023

Vorozhbit, O.Yu., Titova, N.Yu., Kuzmicheva, I.A., \& Borovitskaya, M.V. (2018). Development of competitive advantage evaluation technique for industrial clusters on the basis of M. Porter's national competitiveness model Rhombus transformation. Amazonia Investiga, 7(13), 308-321.

https://amazoniainvestiga.info/index.php/am azonia/article/view/562

Zhang, Y., Tang, Y., Zhang, Y., Sun, Y., \& Yang, H. (2021). Impacts of the COVID-19 pandemic on fish trade and the coping strategies: An initial assessment from China's perspective. Marine Policy, 133, 104748

Zhao, W., \& Shen, H. (2016). A statistical analysis of China's fisheries in the 12th fiveyear period. Aquaculture and Fisheries, 1, 41-49

Zhilina, L.N., \& Krasova, E.V. (2014). State policy of innovation support in Russian shipbuilding: factors of development, goals and priorities. Economics and Entrepreneurship, 1-2 (42), 99-104.

Zhuk, A.P. (2010). Theoretical and methodological foundations of management of innovative and competitive fisheries management in the Far East of Russia. Vladivostok, Russia: Publ. House Dalnauka, 341 https://www.elibrary.ru/item.asp?id=199562 13 